cremaster; abdomen punctured, cases coarsely creased: color uniform dark brown, nearly black. Length I $7 \mathrm{~mm}$.; width $6 \mathrm{~mm}$.

Food-plants. Poplar (Populus tremuloides and $P$. balsamifera). Larvae from Yosemite, Cal.

I moth. Allied to Gluphisia lintneri Grote and $G$. avimacula Hudson. Antennae lengthily bi-pectinated, the pectinations black, with dense, pale ciliae; shaft with whitish hairs. Thorax and abdomen densely clothed with dark gray hairs, black and white mixed, much darkest on thorax, the posterior edge of the collar defined by a paler line. Wings dark gray, nearly white scales intermixed with black scales and hairs, the white predominating in the median space. At the base of fore wings, on median vein, is a small ocherous dot, contiguous to, and forming part of a basal ocherous shading, enclosed in the space between median and internal veins, and bordered outwardly by an obscure, brownish-black, transverse line. Sub-basal space gray, clothed with black and white scales becoming lighter just before the t.a. line. Transverse anterior line distinct, velvety black, outwardly produced on subcostal, median and internal veins and inwardly arcuate across the cell and submedian interspace, most strongly defined at the internal margin. Median space broad, pale gray, with a central blackish shade-line in which is an obscure ocherous crescent at end of cell. Space below median vein next to t.a. line also shaded with ocherous, extending to the t.p. line along internal margin. The veins are slightly lined with black. Transverse posterior line whitish, dentate, preceded and followed by a black shade which is emphasized by the black markings on all the veins before the line, and fills in the subterminal space outside of it. Subterminal line outwardly arcuate to vein 4 , thence again strongly arcuate to the interspace between veins 2 and 3 and thence straight to internal angle. It is shaded with ocherous yellow and bordered outwardly with dark brown; but is narrowly broken on each vein by the gray ground color. Terminal space even, dark gray; fringes spotted with white and blackish brown. Hind wings thinly scaled, dark gray, paler at base, with two transverse pale lines defined by black scales and, on the internal angle, by three distinct black spots, the lower one of which is on the fringe. The outer line is faint, but is tinged with ocherous at the anal angle. Fringe as on fore wings. Beneath, blackish gray; a common extra mesial pale band, bordered inwardly with black. Hind wings whitish centrally. Expanse of wings, $4 \mathrm{I} \mathrm{mm}$.

Mr. Neumoegen has recently proposed the name Melia* (which, however, is preoccupied) for the linterni group of Gluphisia, describing as the type $M$. daubyi. This is the form of Gluphisia severa found in the Northwest, and I do not think it specifically distinct from that which occurs in the Sierra Nevada. I have taken it at Portland, Oregon, and have seen two examples in the collection of Mr. R. H. Stretch, presumably captured in Seattle, Wash.

\section{A COCKS-COMB GALL ON RHUS MICROPHYLLA.}

\section{BY C. H. TYLER TOWNSEND, KINGSTON, JAMAICA.}

On June 16,1892 , I found a gall of very striking appearance, from its deep scarlet color, on Rhus microphylla, near Mud Spring, which is on the road between Las Palomos and Cuchilla Negra, in Sierra county, N. Mex. The gall is of peculiar shape and resembles a cluster of many thickened leaflets massed together. At a casual glance, it might be mistaken for the fruit of the Rhus, which is in clusters and orange-colored but very different in form. The same gall was found next day, June i7, in the upper portion of the small cañon known as the Canada Alamosa. 
Gall.-Average diameter, 15 to $25 \mathrm{~mm}$; length (on twig), about 20 to $30 \mathrm{~mm}$. Galls luster-like, irregular in shape, sometimes, rounded, cocks-comb-like in appearance, springing from the small stems which shoot out laterally from the twig or branch, or terminal portion of latter. Consisting of irreglar massed clusters of many aborted, deformed, greatly thickened and fleshy leaflets springing from the side stems; surrounding the twig or branch but not attached thereto, dark scarlet-red in color on all surfaces exposed to the sun, the under side when not so exposed being annually greenish and always lighter than the upper or exposed portions. Inside portions green. External surface of the gall extremely irregular in outline, the fleshy leaflets arranged in irregular cockscomb-like groups more or less pointed apically, the groups of leaflets longitudinally creased, appearing as though formed of many little columns set side by side and soldered together, much resembling groups of certain columnar crystals.

Described from 3 or 4 galls. The fleshy groups of leaflets contain irregular cavities within them. These, when opened the following spring, revealed only small pale brownish bodies attached to the walls inside. I am unable to suggest the order of insects to which the maker of this gall belongs. It may possibly be an acarid - perhaps a phytoptid.

Tardy wing-expansion in Callosamia.A few days ago I found, in Kensington, N. H., a small wild-cherry tree hung with cocoons of Callosamia Promethea to the number of seventy-five at least. On some twigs six or seven hung close together, all unusually large and light-colored. I cut off over thirty of them, and on June I2th I opened them, finding all good but one, in which the pupa had failed to cast the larvaskin, and so had died. One cocoon contained a $q$ on the point of emerging, the pupa-skin being broken in several places. I took out the half-emerged moth, removed the ragged pupa-skin, and the moth crawled to the top of my cage, and hung there, undeveloped, all day and all night. This morning, June $3^{\text {th }}$ at nine o'clock, its wings were still undeveloped, and I supposed it had been stunted by the unusual mode of emergence. At ten o'clock, however, the wings had expanded to nearly full size, and in half an hour more the moth was a fine specimen, fully developed, and unusually large !

I have never known the wings to expand so many hours after the moth had emerged.

\section{Brookline, Mass.}

Caroline G. Soule.

Entomological Notes. - Insect parasitism is admirably and suggestively treated in Pres. Riley's address to the Entomological society of Washington, just printed in its proceedings. It is worthy of the closest attention as a broad outline of the subject; by the introduction of fuller illustrative details it could easily be expanded into a volume and be a very welcome addition to our literature.

In the last part of the transactions of the Entomological society of London, Dr. David Sharp shows that ants stridulate by means of fine transverse lines on the middle of the dorsum of the third abdominal segment where it is rubbed by the edge of the preceding segment; these organs are usually present in the Ponerides and Myrmicides, but appear to be absent from the Camponotides and Dolichoderides.

A. D. Hopkins prints in Bull. $3^{1}$ of the West Virginia experiment station an interesting Catalogue of West Virginia Scotytidae and their enemies.

Wytsam of Bruxelles announces a new issue of Hübner's Sammlung exotischer schmetterlinge and Zuträge, 664 quarto plates in all, the plates copied by heliogravure and colored by hand; the original and the latest nomenclature will be added. It will appear in 60 equal parts and be sold for 500 francs, payable by parts. 

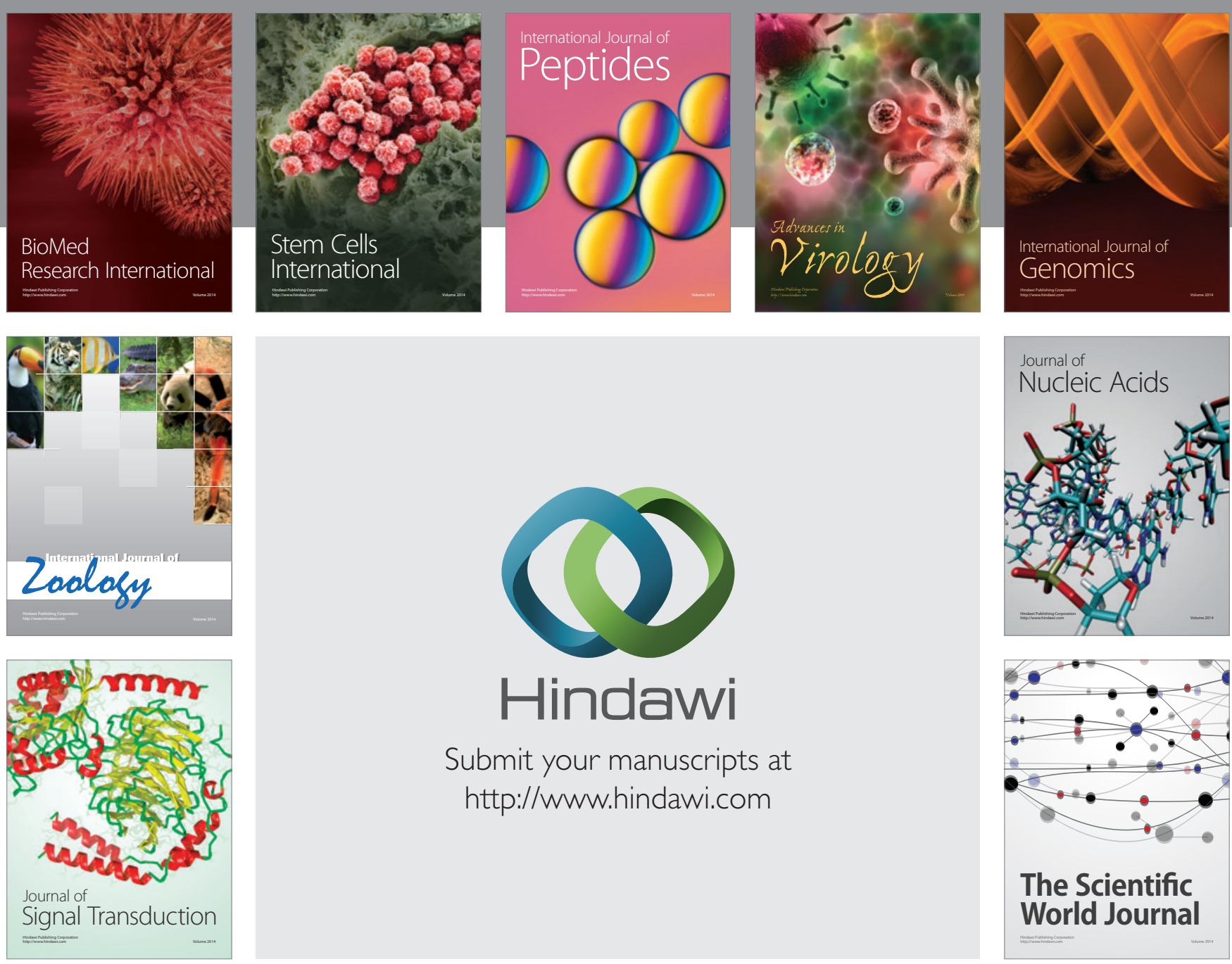

Submit your manuscripts at

http://www.hindawi.com
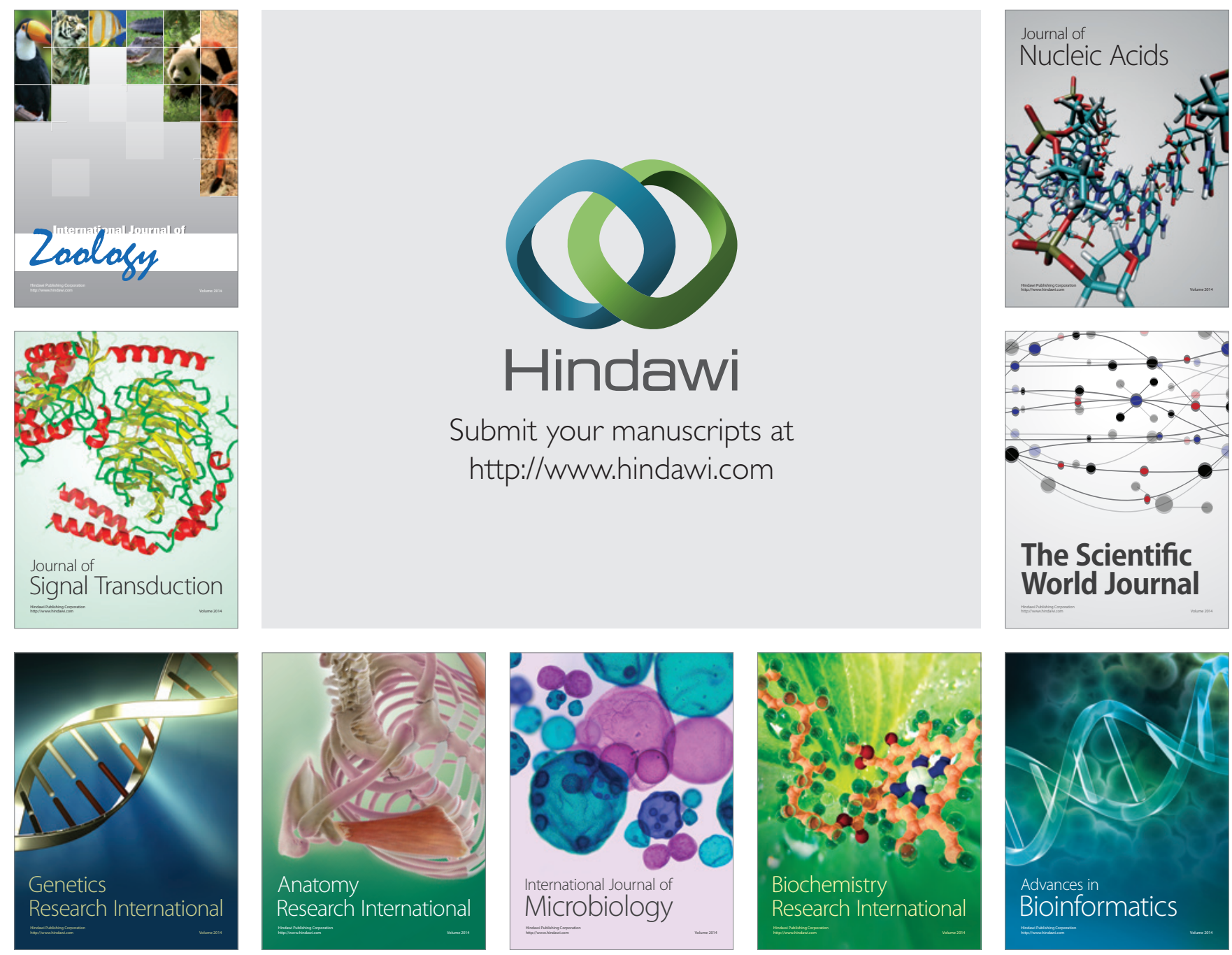

The Scientific World Journal
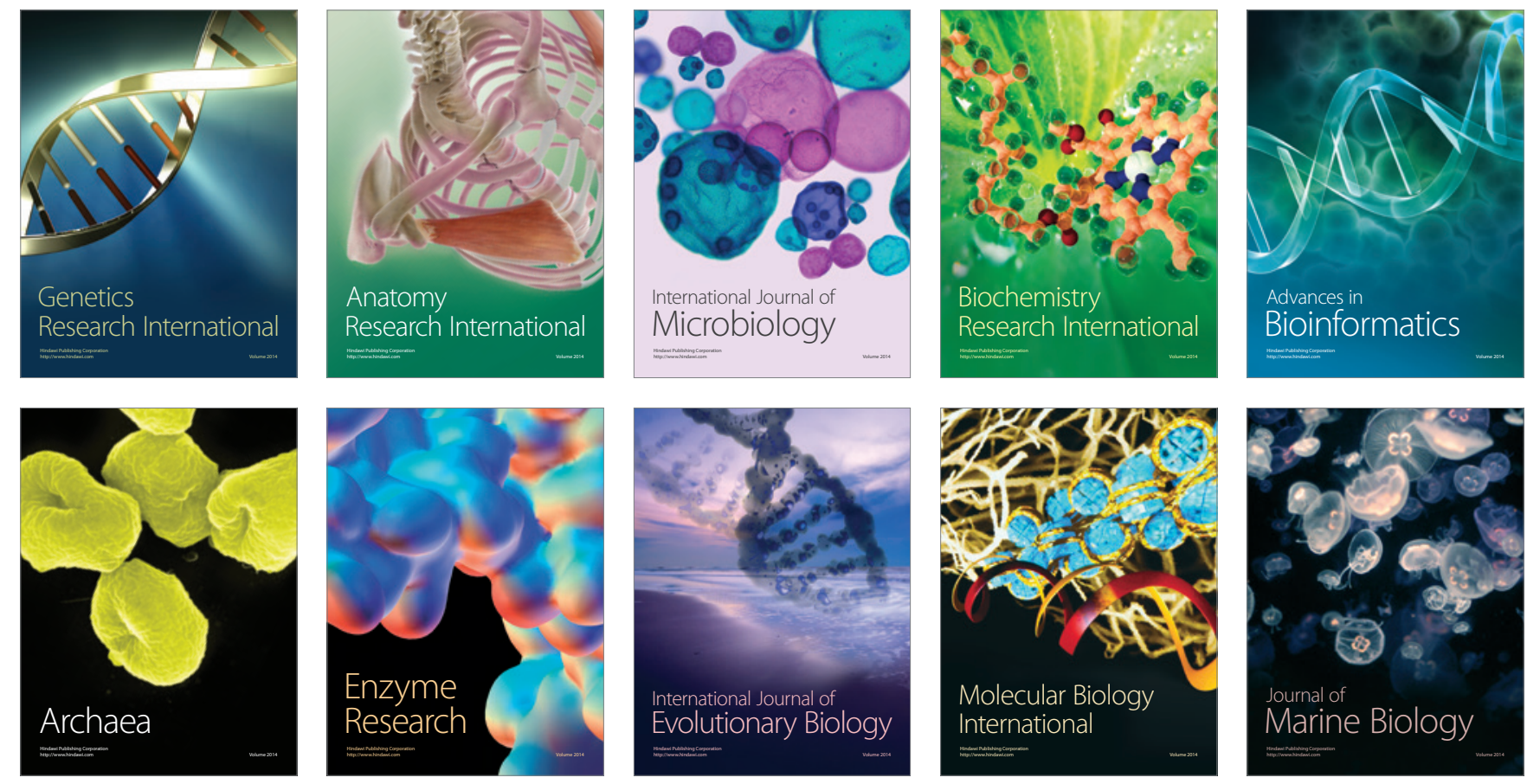